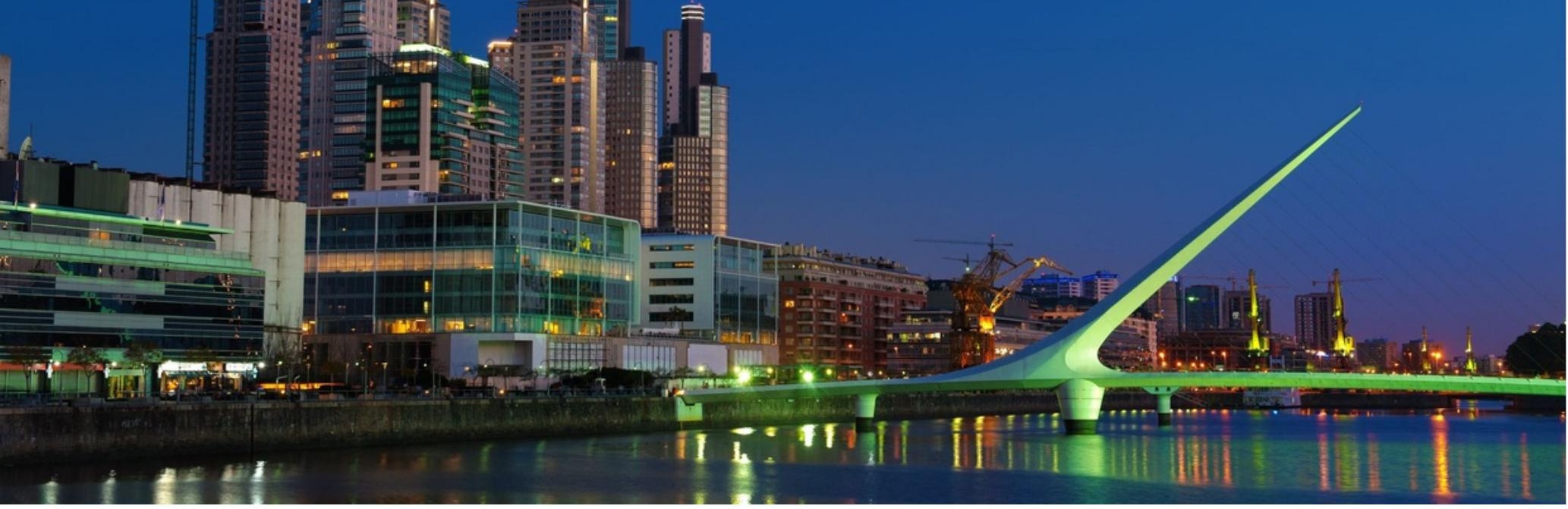

International Congress of Translational MedicineAnnouncement: Buenos Aires, Argentina, Nov 2425, 2015

Authors: Christoph Borner, Cristina Arranz

Submitted:

3. September 2015

Published:

Volume:

Issue:

3. September 2015

2

Keywords:

6

Announcement, Congress, Translational Medicine, Wütherich, Nobel Lecture, Buenos Aires, Argentina

DOI: $\quad$ 10.17160/josha.2.6.60 


\section{$0 \mathrm{O}$ IMBS}

\section{International Congress of Translational Medicine}

\section{Cellular and Molecular Pathways as Therapeutic Targets}

Under the Auspices of the German and Swiss Embassies in Buenos Aires.

$$
\begin{aligned}
& \text { An International Congress of the } \\
& \text { International Master in Biomedical Sciences } \\
& \text { Universidad de Buenos Aires (Argentina) }
\end{aligned}
$$

\section{Preliminary Program: November $24^{\text {th }}$ and $25^{\text {th }}, 2015$.}

Venue: Facultad de Farmacia y Bioquímica UBA - Junín 956 C.A.B.A

\section{Tuesday $24^{\text {th }}$}

14:00- 14:15 hrs. Welcome address by Dean Prof. Cristina Arranz - Facultad de Farmacia y Bioquímica - UBA

Chairperson: Dr. Daniel Turyn

14:15- 15:00 hrs. OPENING LECTURE: Prof. Dr. Daniel Cardinali

\section{Session 1}

Chairpersons: Prof. Dr. Christoph Borner - Prof. Dr. Ralf Baumeister

15:00 - 16:15 hrs. ROUND TABLE. 4 Speakers, 15 minutes each talk (TED Talk Format)

- Prof. Dr. Andreas Zirlik- ALU Freiburg "Danger signalling in atherosclerosis"

- Prof. Dr. José Alejandro Chabalgoity- UdelaR (Talk title to be proposed)

- Speaker 3 to be chosen from UBA Faculty of Medicine

- Speaker 4 to be chosen from UBA Faculty of Pharmacy and Biochemistry

16:15 - 16:30 hrs. Coffee Break and Poster Session

16:30 - 17:30 hrs. SCIENTIFIC POSTERS EXHIBITION AND DISCUSSION

17:30 - 19:00 hrs. ACADEMIC EULOGY

DOCTOR HONORIS CAUSA AWARD

MAIN CONFERENCE by Dr. Kurt Wüthrich, Nobel Prize in Chemistry 2002 


\section{Session 2}

Chairperson: Prof. Dr. Emilio Malchiodi /Prof. Dr. Alicia Brusco

8:30 - 10:00 hrs. ROUND TABLE. 4 Speakers, 15 minutes each talk (TED Talk Format)

- PD Dr. Panagiotis Papatheodorou-ALU Freiburg "Genes, Pathways and Domains involved in the Uptake of Clostridial Toxins"

- Prof. Dr. Rafael Radi - UdelaR(Talk title to be proposed)

- Speaker 3 to be chosen from UBA Faculty of Medicine

- Speaker 4 to be chosen from UBA Faculty of Pharmacy and Biochemistry

10:00 - 10:30 hrs. Coffee Break

Session 3

Chairperson : Prof. em. Dr. Roland Mertelsmann

10:30 - 11:15 hrs. CONFERENCE

11:15 - 12:15 hrs. SCIENTIFIC POSTERS EXHIBITION

12:15 - 13:15 hrs. Lunch Break

\section{Session 4}

Chairpersons: Prof. Dr. Manuel Rodríguez-Prof. Dr. Meike Burger

13:15 - 14:45 hrs. ROUND TABLE. 4 Speakers, 15 minutes each talk (TED Talk Format)

- Prof. Dr. Kristina Schachtrup-ALU Freiburg "Id3 controls Fas-mediated deletion of virus specific CD8 T cell in chronic viral infection"

- Prof. Dr. Jürgen Rühe-ALU Freiburg "It all happens at the interface Tailormade Biointerfaces Through Surface-attached Polymer Networks"

- Prof. Paolo Sarti - Sapienza University of Rome (Talk title to be proposed)

- Speaker 4 to be chosen from UBA Faculty of Pharmacy and Biochemistry

\section{Session 5}

Chairpersons: Prof. Dr. Ralph Wäsch - Dr. Oswald Prucker

14:45 - 15:45 hrs. ROUND TABLE. 3 Speakers, 15 minutes each talk (TED Talk Format)

- Prof. Dr. Paul Fisch-ALU Freiburg "A new type of acquired immunodeficiency in thymoma"

- Speaker 3 to be chosen from UBA Faculty of Medicine

- Speaker 4 to be chosen from UBA Faculty of Pharmacy and Biochemistry

15:45 - 16:15 hrs. Coffee Break and Poster Session

Session 6

Chairperson: Prof. Dr. Ricardo Gelpi

16:15 - 17:00 hrs. CONFERENCE

17.30 - 18:00 hrs CLOSING CEREMONY and OUTSTANDING POSTERS AWARDS: 